\title{
Investigating the Relationship between Organizational Culture and Organizational Justice among Health Workers in Turkey
}

\author{
Servet KAYA, Hikmet SEÇIM \\ Cyprus International University Haspolat, Turkey \\ servet_kaya03@yahoo.com
}

\begin{abstract}
To achieve profits, management has to put in place several inputs. Of all the inputs, human resources or the employees are the most important and yet, the most unpredictable. Research has identified organizational culture and organizational justice as two factors enabling employee satisfaction. Upon, their identification, research has continued into these areas as two separate fields and has come up with several results. However, little is known on how these two interrelate and their effect on one another. This study sought to provide this information by investigating the correlation between these two factors. To do this, a cross-sectional survey was carried out among 223 health workers from a public hospital in Malatya, Turkey during May and June 2014. Out of a maximum of 20, organizational culture and organizational justice received mean scores of $11.4 \pm 2.3$ and $14.0 \pm 4.8$ respectively. Correlation analysis showed that almost all the domains of organizational culture had a statistically significant moderately positive relationship $0.434 \leq \mathrm{r} \leq$ 0.636) with the domains of organizational justice with the exception of the power domain. This study finds a statistically positive correlation between overall justice scores and overall culture scores. However the correlation between them is moderate indicating that it is possible that other factors are equally or even more important in their determination. Thus, while managers can use organizational culture as an indication of organizational justice, they should not totally rely on one as a measure of the other.
\end{abstract}

Keywords: Organizational Culture, Organizational Justice, employee perception, human resource management, health workers

\section{Introduction}

Staff associated with an establishment has their own motives for joining the company. A function of the companies is usually to be a source of developing human relationships (Desson \& Clouthier, 2010). When faced with problems, companies provide possible solutions. This is the point of connect for organizational culture. The main concern of organizations is to make profits. However, to achieve this, organizations must ensure a secure and healthy environment for the employees through which they can reach their goals. Organizational culture points to behaviours done by a set of people inside a company. Employees incline towards certain attitudes to conform and be efficient (Peters \& Waterman, 1982). We can then say that organizational culture compresses of norms and values. Organizational justice is another major part of viable companies. It is a function of how fair a company is (Colquitt, Conlon, Wesson, Porter \& Ng, 2001). Organizations could their employees to adapt their values and norms via their cultures. Thus, they may constitute a link between their staff and institution. Successful businesses shape their organizational culture in accordance with their aims and objectives and take precautions to protect this (Schneider, Ehrhart, \& Macey, 2013). The effect of organizational culture on how justice is viewed has also great importance on employees in the aspects of catching organizational aims and making employees adapted to organization. The ones who have not organizational justice perception, which also includes justice perception in working environment can not adapt organizational culture. The importance of both organizsational culture and justice to the cohesiveness of employees and in turn continued successs of the business has been established on other studies (Schein, 2006; Shao, Rupp, Skarlicki \& Jones, 2013). Recent development in the study of organizational justice has seen the development of new domains as well as multi-level research into group setings as to the interactions between the various domains of organizational justice (Goodin, 2010; Usmani \& Jamal, 2013). However, little is known as regards the role of organizational culture in either promoting or hindering organizational justice. This information is crtical to managers as it would increase their understanding of the mechanics that shape organizational culture and justice, both factors which are of 
immense importance to rowth and success of their establishment. This study seeks to provide this information by investigating the relationship of organizational culture with organizational justice.

\section{Literature Review}

Organizational Justice: The concept of organisational justice, originated from Greenberg in 1987, and it is the way an employee perceives the company's deeds, choices and engagements and the way they influence the staffs' own attitudes and actions. Organizational justice is a term very similar to concept of fairness. In every organization, employees are sensitive to decisions made on an everyday basis by their employers and/or management, and group them as either unfair or fair. The pattern of these judgements influences the employee's behaviour and has been shown to have an effect on employee motivation, retention and output. The importance of organizational justice should be of paramount importance to the management as it is critical to the success of any establishment. In fact, it has been described as the glue that allows employees to work together in an effective manner (Cropanzana, Bowen \& Gilliland, 2007). The importance of organizational justice has resulted in the large amount of literature available to managers on the subject in relation to many other aspects of the workplace (Frenkel, Li \& Restubog, 2012; Shao et al., 2013). Analysis of the literature on organizational justice has revealed 3 major parts to organizational justice, i.e. distributive justice, procedural justice and interactional justice.

Distributive justice: Distributive justice has to do with the allocations or outcomes that some employees get and others do not. Distributive justice deals with the basic truth that it is impossible to treat all employees in the exact same way. Thus, distributive justice requires that the distribution of results is segregated in the workplace based on the share of input received by each employee. Thus, employees are worried with the proportion of their input to their rewards. This description of distributive justice has its backgrounds grounded in the equity theory. Cropanzana, Bowen, \& Gilliland (2007) opine that the equity theory is interested in the ratio of how much employees get to how much we contribute. Thus, it would be termed as distributive fair if a particular employee received less than another but was also expected to contribute less than his colleague with the higher pay. However, modern developments in the study of distributive justice have highlighted other components or factors that are to be taken into consideration in the conceptualizing distributive justice. The allocation rules of equality (to each the same), and need (to each in accordance with the most urgency) have also gained prominence with researchers suggesting that the management does not have to sacrifice one allocation rule for the other but rather adopt a mix that best suits their organization (Colquitt, Greenberg, \& Zapata-Phelan, 2005).

Procedural Justice: Procedural justice is the ways by which results are apportioned. Leventhal (1980) and Leventhal, Karuza, \& Fry (1980) originated research work in the area of procedural justice and concluded that it consists of the basic principles of consistency (implying staff are given equal treatment), lack of bias (implying no discrimination) and correctness when making decisions. In addition, procedural justice deals with the methods used in reaching decisions, emphasizing such principles as the fact that decisions must be reached after adequate input by all stakeholders and that norms of practice are not violated(Cohen-Charash \& Spector, 2001; Colquitt et al., 2005).Studies show that even in the cases of unfavourable decisions, adequate attention to procedural justice can lead to greater support of the decisions and increased $t$ rust and commitment to the employers. For example, Mauborgne \& Kim (2005) in their book opined that fair processes had the ability to stimulate intellectual and emotional recognition which, in turn, builds trust and commitment culminating in voluntary cooperation in execution of agreed decisions.

Interactional justice: It simply alludes to the manner of treatment of a person $t$ o another. Interactional justice is exhibited when information is shared to all who require it in an appropriate manner with speech lacking in vulgar or lewd remarks (Blodgett, Hill \& Tax, 1997). Colquitt et al. (2001) grouped interactional justice in to two main aspects. The first aspect, otherwise known as informational justice refers to the truthfulness of an employee and/or employer and the provision of adequate justifications when results do not come out as favorably as expected. The second part, also known as interpersonal justice, refers to the respect and dignity with which one treats another (Bies \& Moag, 1986; Blodgett et al., 1997; Skarlicki \& Folger, 1997). Both aspects are equally important. Since interactional justice focuses on personalized transactions, employees often request it from supervisors or the management. Thus, as found out in a study 
by Skarlicki \& Latham (1996), training supervisors and management staff to provide explanations and apologies (informational justice) and to treat their reports with courtesy and respect (interpersonal justice) yielded improved relations with the employees. Current research on organizational justice has provided 2 new components of organizational justice. They are temporal and spatial justice

Temporal justice: Goodin (2010)originated the idea of time justice with emphasis the authority each individual has over his or her time. He defined it as 'having discretionary control over one's time'. This new component of organizational justice arose out from the same concept but in a different setting. Temporal justice in an organization is concerned with fair distribution of time. It is a function of how each employee views the amount of time given him to complete tasks or in another sense how time-consuming his tasks are (Usmani \& Jamal, 2013).

Spatial justice: In general terms, spatial justice is a fixated and thoughtful stress on the geographical domain of justice. It is the equitable allocation of resources across geographical units (Usmani \& Jamal, 2013). Geologically irregular improvement also provides a context for understanding injustice in the workplace (Soja, 2009). Spatial justice has an impact on the circulation of resources across zones (Lefebvre, 1968 \& 1972). Present-day research into organizational justice has shed light on the factors that make staff care about justice (content theories) and the procedures that result in both the creation of fairness perceptions, e (process theories) (Rupp, 2011). In addition, recent research also has shifted attention from studying the degree to which employees view themselves as being treated fairly to how employees perceive the treatment of others as either fair or unfair. This has also led researchers to consider employees' reactions to corporate social responsibility which is now being treated as a special case of third-party justice perceptions (Skarlicki \& Rupp, 2010; Topa, Moriano \& Morales, 2013). Finally, research on organizational justice has become more and more multilevel, exploring how shared perceptions of justice form within work groups and organizations (justice climate), and has dealt with how justice perceptions and reactions vary across cultural groups (e.g., organizational and national cultures) (Li \& Cropanzano, 2009; Rupp, 2011).

Organizational Culture: Organizational culture has been defined as "a pattern of shared basic assumptions that was learned by a group as it solved its problems of external adaptation and internal integration, that has worked well enough to be considered valid and, therefore, to be taught to new members as the correct way to perceive, think, and feel in relation to those problems" (Schein, 2006). With this definition, it becomes obvious that the term organizational culture applies to any institution be it schools, clubs, governments, companies or even the family. It is developed over time as continued patterns of thinking and actions eventually become routine and acceptable to any group. In fact, such pattern becomes a norm that it becomes expected of members of such a group, with anyone not adhering to it seen as being odd or a misfit. Research bearing on the topic of organizational culture dates as far back as the Henry Mayo studies of the 1930's when he described work group cultures. However, the delineation of organizational culture as a field of its own did not occur until the 1980's when researchers such as Deal and Kennedy (1984), Ouchi(1981), and Peters and Waterman (1982) published their books on the subject. Since then, the body of academic literature bearing on the subject as a real one with tangible effects has grown. Researchers have deduced that organisational culture is just like the personality of an individual.

However due to the different perspectives from which the several authors have looked at organizational cultures, there have been many definitions and determinants associated with organisational culture. For instance, while Deal and Kennedy (1982) named four broad kinds of cultures, namely the tough-guy/macho culture, "the work-hard/play-hard culture, the bet-your company culture and the process culture", Handy, (1996) explained organisational culture by via4kinds of classifications, "power, role, task and person cultures. Continued research into organization culture came up with the organizational culture model. This descriptive model is aimed at investigating the discrepancies if any between the prevailing and favoured cultures in a company. The organisational culture model lists the four dimensions of culture orientation (power, role, achievement and support) and measures them in two manners of operation, namely formalisation and centralisation (Carroll \& Harrison, 1998). Each mode can then be quantified as either high or low.

Importance of organizational culture: As has been deduced from management theory, organizational culture has powerful effects on the way organizations and its members think and behave. Thus organizations 
with the right kind of culture that matches with the kind of enterprise in which an organization is engaged has been generally noticed as being among the most important factors of how effective or successful the organization will be. Barney (Barney, 1986)attributed the continued financial excellence of major conglomerates as Procter and Gamble, MacDonald's etc. to their strong organizational culture. Other benefits of a strong organizational culture include being a powerful lever for guiding behaviour (Deal \& Kennedy, 1982), facilitates goal alignment (Brown \& Dodd, 1998) and cohesiveness, loyalty, lower employee turnover and organisational commitment among employees (Martins \& Terblanche, 2003). All of these benefits are garnered because of the manner in which organisational culture shapes several aspects of an organisation's activities. Examples are:

- Making right decisions

- Appropriate behaviour and work relationships

- Manner of task implementation

- Efficacy of processes

- Willingness to adapt and

Summarily, the kind of culture prevalent in an organization is an indicator of the level of success of new initiatives embarked upon by the organization and the possibility of it achieving its overall goals.

\section{Methodology}

The aim of this study is to examine the relationship between organizational culture and organizational justice. To do this, the study will determine the perceptions of staff on each of the dimensions of culture and justice that are overwhelming and available in organization. The quantitative research methods were used in this study for data collection purposes. Quantitative approach is considered to be the best way to measure individual's perceptions because, as stated by Edwards (1998), "quantitative methods have the advantage of allowing researchers to measure and control variables.survey research method was conducted to measure the relationships among studied concepts". This method allows for statistical analysis, and more time efficient (Meredith, Raturi, Amoako-Gyampah, \& Kaplan, 1989).

Hypothesis: The hypothesis which was adopted by the study as follows:

$\mathrm{H}_{0}$ : There is a no relationship between dimensions of culture (achievement, support and hierarchy) and justice (procedural, interactional and distributive).

$\mathrm{H}_{1}$ : There is a relationship between dimensions of culture (achievement, support and hierarchy) and justice (procedural, interactional and distributive).

Sample: The data were collected from 258 full-time health care employees from a public hospital in Malatya, Turkey during May and June 2014. 35 surveys had to be discarded due to incomplete information. 223 surveys were included in the analysis.

Instruments: NihalMamatoğlu (2006) developed organizational culture scale using the Harrison's organizational culture model (hierarchy, achievement, power, support). The questionnaire has 16 questions and quantifies each of the 4 domains of organizational culture. Each of these domains has 4 structured questions to measure it. The questionnaire used a five-point Likertscale for respondents to rate dimensions of organizational culture. The Organizational Justice scale was adapted for use in this study. It is a standardized questionnaire developed by Colquitt et al. (2001) it consists of 20 items measuring the 3 domains of justice this study seeks to examine i.e.distributive, procedural and interpersonal justice. The items are rated on a 5point scale $(1=$ "Very few" to $5=$ "Substantially"). Reliablity tests were conducted on data received from a pre-test among a similar population in another city (Istanbul), Cronbach Alpha scores of 0.94 was obtained indicating that the ability of the questionnaire to measure what is intended is very strong. Overall scores were calcluated by adding the scores for the individual domains.

\section{Results and Discussion}

Socio-demographic characteristics: Almost two-thirds of the respondents (65.9\%) were female with other $76(34.1 \%)$ as male. One hundred and seventy-six respondents representing a little more than three-quarters 
(78.9\%) were married leaving 47 respondents $(21.1 \%)$ as single. The majority of the respondents had completed tertiary education (76.7\%). The rest of the socio-demographic characteristics are shown in

Table 1.

Table 1: Socio-demographic characteristics of respondents

\begin{tabular}{lll}
\hline & $\mathbf{N}$ & $\mathbf{\%}$ \\
\hline Gender & 76 & 34.1 \\
Male & 147 & 65.9 \\
Female & & \\
Age Group & 4 & 1.8 \\
Under 20 & 43 & 19.3 \\
20-29 & 103 & 46.2 \\
30-39 & 57 & 25.6 \\
40-49 & 16 & 7.2 \\
50 and above & & \\
Marital Status & 47 & 21.1 \\
Single & 176 & 78.9 \\
Married & 52 & \\
Educational level & 171 & 23.3 \\
Basic & & 76.7 \\
Tertiary & 23 & 10.3 \\
Job position & 84 & 37.7 \\
Doctor & 116 & 52.0 \\
Nurse & & \\
Other & 151 & 67.7 \\
Tenure & 72 & 32.3 \\
10 years or less & & \\
Above 10 years & 64 & 28.7 \\
Wage & 159 & 71.3 \\
0-2000 Tl & & \\
More than 2000Tl & 165 & 74.0 \\
Work status & 58 & 26.0 \\
Public & & \\
Private & & \\
\hline
\end{tabular}

Culture and Justice Scores: The average score for each of the variables is listed in

Table 2. It shows that all 4 domains of the organizational culture category had around the same average scores $(\mathrm{Max}=12.7, \mathrm{Min}=10.5)$. Of the 4 domains however, power domain had the highest score $(12.7 \pm 2.7)$ with hierarchy having the least score $(10.5 \pm 3.3)$. In the organizational justice category, greater variance was observed between the domains. While interactional justice had a very high score (17.3 \pm 6.7$)$, distributive justice had below average scores $(9.8 \pm 4.3)$. The overall average score for organizational justice was $14.0 \pm$ 4.8 .

Table 2: Descriptive statistics for Culture and Justice Scores

\begin{tabular}{lll}
\hline Category & Variable & Mean* \pm S.D \\
\hline & Achievement & $11.2 \pm 3.4$ \\
CULTURE & Power & $12.7 \pm 2.7$ \\
& Support & $11.2 \pm 3.3$ \\
& Hierarchy & $10.5 \pm 3.3$ \\
& Overall & $11.4 \pm 2.3$ \\
& Procedural & $14.8 \pm 5.3$ \\
JUSTICE & Interactional & $17.3 \pm 6.7$ \\
\hline
\end{tabular}




\section{Overall}

$14.0 \pm 4.8$

* The maximum score for each domain is 20 and minimum is 0

Relationship between organizational justice and organizational culture: Inferential analysis was carried out on the various domains of both organizational culture and organizational justice. Results show that there moderately positive correlations between the domains of organization and the domains of organizational justice, with all the results being significant at less than $0.1 \%$. The stand out results however, were in the correlation of the power domain, where power was negatively correlated with each of the domains of organizational justice and with the overall scores for organizational justice $(-0.149 \leq r \leq-0.071)$. However, of the four correlation results, the only one statistically significant at $5 \%$ level of significance was the correlation between the power domain and distributive justice $(p=0.026)($

Table 3).

Table 3: Correlation analysis between organizational culture and organizational justice

\begin{tabular}{|c|c|c|c|c|c|}
\hline & & \multicolumn{4}{|c|}{ ORGANIZATIONAL JUSTICE } \\
\hline & & $\begin{array}{l}\text { Procedural } \\
\text { R } \\
\text { (p-value) }\end{array}$ & $\begin{array}{l}\text { Interactional } \\
\mathbf{R} \\
\text { (p-value) }\end{array}$ & $\begin{array}{l}\text { Distributive } \\
\mathbf{R} \\
\text { (p-value) }\end{array}$ & $\begin{array}{l}\text { Overall } \\
\mathbf{R} \\
\text { (p-value) }\end{array}$ \\
\hline \multirow{5}{*}{ 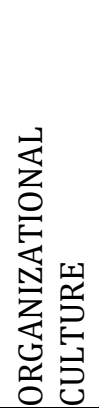 } & Achievement & $\begin{array}{l}0.582 \\
(<0.001)\end{array}$ & $\begin{array}{l}0.557 \\
(<0.001)\end{array}$ & $\begin{array}{l}0.446 \\
(<0.001)\end{array}$ & $\begin{array}{l}0.606 \\
(<0.001)\end{array}$ \\
\hline & Power & $\begin{array}{l}-0.071 \\
(0.288)\end{array}$ & $\begin{array}{l}-0.124 \\
(0.065)\end{array}$ & $\begin{array}{l}-0.149 \\
(0.026)\end{array}$ & $\begin{array}{l}-0.128 \\
(0.056)\end{array}$ \\
\hline & Support & $\begin{array}{l}0.636 \\
(<0.001)\end{array}$ & $\begin{array}{l}0.570 \\
(<0.001)\end{array}$ & $\begin{array}{l}0.434 \\
(<0.001)\end{array}$ & $\begin{array}{l}0.629 \\
(<0.001)\end{array}$ \\
\hline & Hierarchy & $\begin{array}{l}0.570 \\
(<0.001)\end{array}$ & $\begin{array}{l}0.545 \\
(<0.001)\end{array}$ & $\begin{array}{l}0.493 \\
(<0.001)\end{array}$ & $\begin{array}{l}0.610 \\
(<0.001)\end{array}$ \\
\hline & Overall & $\begin{array}{l}0.622 \\
(<0.001)\end{array}$ & $\begin{array}{l}0.565 \\
(<0.001)\end{array}$ & $\begin{array}{l}0.450 \\
(<0.001)\end{array}$ & $\begin{array}{l}0.626 \\
(<0.001)\end{array}$ \\
\hline
\end{tabular}

Multiple regression analyses were run to predict the overall justice score from each of the domains of organizational culture. These variables statistically significantly predicted overall justice score $\mathrm{F}(4,218)=$ $51.613, p<0.001 R^{2}=0.486$. All the four domains added statistically significantly to the prediction $(p<0.05)$ (Table 4)

Table 4: Regression Analysis for Overall Justice Score

\begin{tabular}{lllll}
\hline Dependent variable & Independent variables & $\mathbf{R}^{2}$ & Beta & \\
\cline { 5 - 5 } Overall Justice Score & & & \\
& Achievement & & 0.486 & 0.002 \\
& Power & & -0.202 & 0.01 \\
& Support & 0.431 & 0.22 \\
& Hierarchy & 0.384 & $<0.001$ \\
& & & & $<0.001$ \\
\hline
\end{tabular}

Similar results were obtained by Usmani and Jamal (2013) in their study on organizational justice. The difference in the power domain observed could be as a result of the fact that Usmani and Jamal conducted their study in Pakistan, a country Hofstead (1997) described as being high on power distance to the extent that the employees almost take it as a requirement for them to face injustices from their superiors at work. They may be ignorant about employee rights and the concept of equity within a company. And if they did, fear of being laid off as well as a high unemployment rate makes them accept whatever conditions there are presented with. On the contrary, Turkey belongs to Europe where employee rights are well recognized and workers do not fear being unfairly treated due to their opinions. The average scores received in the justice domains were also similar to those obtained by Kivimäki, Elovainio, Vahtera, \& Ferrie, (2003) in their study on organizational justice in Finland. This may be due to the fact that both Countries are in the same continent and as such similar circumstances prevail in the workplace. The lowest scores of distributive justice may be a pointer to the continued shift of the management from focusing on how to distribute resources to their 
manner of decision making and interaction with employees. The highest scores in the interactional justice domain further pint to this fact. This study finds a statistically positive correlation between overall justice scores and overall culture scores. However the correlation between them is moderate indicating that it is possible that other factors are equally or even more important in their determination. Thus, managers should not totally rely on one as a measure of the other.

This study was conducted to snapshot the perceptions of the health care employees at a time and analysis have been performed with the help of their responses. Identifying the changes on the perceptions of the health care employees after a period of time may be valuable for the researchers for achieving a better understanding on these concepts. The changes and the reasons of the changes maybe helpful for the managers in making correction in their organization culture, work environment, management styles, and job and organization related arrangements. So, a longitudinal study may be applied to evaluate the shift in time. This study is conducted with the participation of a state hospital organizations in Malatya, Turkey. A broader study may be applied the proposed model to various hospitals from various countries.

\section{Conclusion}

Practically speaking, knowing how perceived distributive justice and procedural justice affect the organizational culture can influence management decisions in determining the mechanism to effect in order to ensure that employees are committed and goals are met. This study finds a statistically positive correlation between overall justice scores and overall culture scores. However the correlation between them is moderate indicating that it is possible that other factors are equally or even more important in their determination. Thus, managers should not totally rely on one as a measure of the other.

\section{References}

Barney, J. B. (1986). Organizational Culture: Can It Be a Source of Sustained Competitive Advantage? Academy of Management Review, 11(3), 656-665.

Bies, R. J. \& Moag, J. S. (1986). Interactional justice: Communication criteria of fairness. Research on Negotiation in Organizations, 1(1), 43-55.

Blodgett, J. G., Hill, D. J. \& Tax, S. S. (1997). The effects of distributive, procedural, and interactional justice on postcomplaint behavior. Journal of Retailing, 73(2), 185-210.

Brown, F. W. \& Dodd, N. G. (1998). Utilizing organizational culture gap analysis to determine human resource development needs. Leadership \& Organization Development Journal, 19(7), 374-385.

Carroll, G. R. \& Harrison, J. R. (1998). Organizational demography and culture: Insights from a formal model and simulation. Administrative Science Quarterly, 3, 637-667.

Cohen-Charash, Y. \& Spector, P. E. (2001). The Role of Justice in Organizations: A Meta-Analysis. Organizational Behavior and Human Decision Processes, 86(2), 278-321. http://doi.org/10.1006/obhd.2001.2958

Colquitt, J. A., Conlon, D. E., Wesson, M. J., Porter, C. O. \& Ng, K. Y. (2001). Justice at the millennium: a metaanalytic review of 25 years of organizational justice research. Journal of Applied Psychology, 86(3), 425.

Colquitt, J. A., Greenberg, J. \& Zapata-Phelan, C. P. (2005). What is organizational justice? A historical overview. Handbook of Organizational Justice, 1, 3-58.

Cropanzana, R., Bowen, D. E. \& Gilliland, S. W. (2007). The management of organizational justice. The Academy of Management Perspectives, 2, 34-48.

Deal, T. E. \& Kennedy, A. A. (1982). Corporate cultures: The rites and rituals of organizational life. Reading/T. Deal, A. Kennedy-Mass: Addison-Wesley, 2, 98-103.

Desson, K. \& Clouthier, J. (2010). Organizational culture-why does it matter? In The Symposium on International Safeguards, International Atomic Energy Agency Vienna, Austria, IAEA-CN-184/315, available at: www. iaea. org/safeguards/Symposium/2010/Documents/PapersRepository/315. pdf (accessed 24 August 2013). Retrieved from http://www.iaea.org/safeguards/Symposium/2010/Documents/PapersRepository/315.pdf

Edwards, D. J. (1998). Types of case study work: A conceptual framework for case-based research. Journal of Humanistic Psychology, 38(3), 36-70. 
Frenkel, S. J., Li, M. \& Restubog, S. L. D. (2012). Management, Organizational Justice and Emotional Exhaustion among Chinese Migrant Workers: Evidence from two Manufacturing Firms: Management, Organizational Justice and Emotional Exhaustion. British Journal of Industrial Relations, 50(1), 121147. http://doi.org/10.1111/j.1467-8543.2011.00858.x

Goodin, R. E. (2010). Temporal justice. Journal of Social Policy, 39(01), 1-16.

Hampden-Turner, C. (1990). Creating corporate culture: from discord to harmony. Retrieved from http://pgimrepository.cmb.ac.lk:8180/handle/123456789/12306

Handy, C. B. (1996). Gods of management: The changing work of organizations. Oxford University Press, USA. Retrieved from http://books.google.com/books?hl=en\&lr=\&id=cG6fmxkJo0C\&oi=fnd\&pg=PA3\&dq=Handy+(1985)+described+organisational+culture +by+using +four+t ypes+of+classification+power,+role,+task+and+person+cultures.\&ots=VAo84VHBM\&sig=vqMRDlvZ0n8iKHnhqce65guVeD0

Hofstede, G. (1991). Cultures and organisations-software of the mind: intercultural cooperation and its importance for survival. McGraw-Hill.

Kivimäki, M., Elovainio, M., Vahtera, J. \& Ferrie, J. E. (2003). Organisational justice and health of employees: prospective cohort study. Occupational and Environmental Medicine, 60(1), 27-34.

Lefebvre, H. (1968). La vie quotidienne dans le monde moderne (Vol. 162). Gallimard Paris. Retrieved from http://www.sidalc.net/cgibin/wxis.exe/?IsisScript=BIBA.xis\&method=post\&formato=2\&cantidad=1 \&expresion $=\mathrm{mfn}=005651$

Lefebvre, H. (1972). La vida cotidiana en el mundo moderno. Retrieved from http://www.sidalc.net/cgibin/wxis.exe/?IsisScript=INESI.xis\&method=post\&formato $=2 \&$ cantidad $=1 \&$ expresion $=m f n=001891$

Leventhal, G. S. (1980). What should be done with equity theory? New approaches to the study of justice in social relationships. Social Exchange: Advances in Experimental and Social Psychology, 9, 91-113.

Leventhal, G. S., Karuza, J. \& Fry, W. R. (1980). Beyond fairness: A theory of allocation preferences. Justice and Social Interaction, 3, 167-218.

Li, A. \& Cropanzano, R. (2009). Fairness at the group level: Justice climate and intraunit justice climate. Journal of Management, 35(3), 564-599.

Mamatoglu, N. (2006). Örgüt İçi İletişim ve Performans Değerlendirme Sistemi Algıları Örgüt Kültürü Algısını Yordar mı? Ankara Üniversitesi SBF Dergisi, 61(4). Retrieved from http://dergipark.ulakbim.gov.tr/ausbf/article/download/5000093074/5000086531

Martins, E. C. \& Terblanche, F. (2003). Building organisational culture that stimulates creativity and innovation. European Journal of Innovation Management, 6(1), 64-74.

Mauborgne, R. \& Kim, W. C. (2005). Blue Ocean Strategy-How to Create Uncontested Market Space and Make Competition Irrelevant. TRINH VAN PHUC.

Meredith, J. R., Raturi, A., Amoako-Gyampah, K. \& Kaplan, B. (1989). Alternative research paradigms in operations. Journal of Operations Management, 8(4), 297-326.

O’Reilly, C. A., Chatman, J. \& Caldwell, D. F. (1991). People and organizational culture: A profile comparison approach to assessing person-organization fit. Academy of Management Journal, 34(3), 487-516.

Ouchi, W. (1981). Theory Z: How American business can meet the Japanese challenge. Business Horizons, $24(6), 82-83$.

Özmen, Ö. N., Arbak, Y. \& Özer, P. S. (2007). Adalete verilen değerin adalet algıları üzerindeki etkisinin sorgulanmasına iliş̧kin bir araştırma. Ege Akademik Bakış, 7(1), 17-33.

Peters, T. \& Waterman, R. (1982). In search of excellence: Lessons from America's best-run corporations. New York: Warner.

Rupp, D. E. (2011). An employee-centered model of organizational justice and social responsibility. Organizational Psychology Review, 1(1), 72-94. http://doi.org/10.1177/2041386610376255

Schein, E. H. (2006). Organizational culture and leadership (Vol. 356). John Wiley \& Sons. Retrieved from http://books.google.com/books?hl=en\&lr=\&id=xhmezDokfnYC\&oi=fnd\&pg=PR11\&dq=organization al+culture\&ots=m6IT3L13iO\&sig $=Q 6$ rau1x3Yzr3wcieA88b5H3Ffis

Schneider, B., Ehrhart, M. G. \& Macey, W. H. (2013). Organizational Climate and Culture. Annual Review of Psychology, 64(1), 361-388. http://doi.org/10.1146/annurev-psych-113011-143809

Shao, R., Rupp, D. E., Skarlicki, D. P. \& Jones, K. S. (2013). Employee Justice Across Cultures: A Meta-Analytic Review. Journal of Management, 39(1), 263-301. http://doi.org/10.1177/0149206311422447

Skarlicki, D. P. \& Folger, R. (1997). Retaliation in the workplace: The roles of distributive, procedural, and interactional justice. Journal of Applied Psychology, 82(3), 434. 
Skarlicki, D. P. \& Latham, G. P. (1996). Increasing citizenship behavior within a labor union: A test of organizational justice theory. Journal of Applied Psychology, 81(2), 161.

Skarlicki, D. P. \& Rupp, D. E. (2010). Dual processing and organizational justice: the role of rational versus experiential processing in third-party reactions to workplace mistreatment. The Journal of Applied Psychology, 95(5), 944-952. http://doi.org/10.1037/a0020468.

Soja, E. (2009). The city and spatial justice. Justice Spatiale, Spatial Justice, 1, 31-39.

Topa, G., Moriano, J. A. \& Morales, J. F. (2013). Organizational injustice: third parties' reactions to mistreatment of employee. Psicothema, 25(2), 214-221.

Usmani, S. \& Jamal, S. (2013). Impact of distributive justice, procedural justice, interactional justice, temporal justice, spatial justice on job satisfaction of banking employees. Review of Integrative Business \& Economics Research, 2(1), 351-383. 